\title{
Mawar (Melawan Rentenir): Integrated Msme's Financial Inclusion Strategy in Sharia-Based
}

Amalia Nur Chasanah, Risanda Alirastra Budiantoro, Febrianur Ibnu Fitroh Sukono Putra*, Ratna Herawati

Department of Management, Economics and Business Faculty, Dian Nuswantoro University

*Corresponding author:

E-mail: fbr10@dsn.dinus.ac.id

\begin{abstract}
Allah has provided Islam as life guidance to be used in taking and undergoing all life aspects, including management and business financing. In the perspective of Islamic finance, financing venture capital through moneylenders will make the borrower in a difficult situation. This research aims to analyze the integrated financial inclusion strategy in sharia-based MSME's financing in the Semarang City with the MAWAR Program. Mawar program is a funding assistance program for potential micro small and medium entrepreneurs based on sharia with Murabahah by collaborating through a memorandum of understanding with several other agencies, such as Sharia People Financing banks, Semarang City Amil Zakat Agency, Semarang Syariah Economic Community, Semarang City Cooperatives and Micro Enterprises Agency, telecommunications companies, branchless banking agents and financial technology institutions. The benefit obtained can provide scientific contributions to empowerment management and can be developed into a study material for long-term planning programs by the Semarang City Government in empowering micro, small and medium enterprises so they can be competitive, independent, prosperous, and cultured based on religiosity values. The approach method used qualitative research with analytical tools is the business model canvas. Data collection method used observation, interviews, and literature study. The results of this research are with the MAWAR Program, the Semarang City Government does not charge any additional costs to the borrowers (MSME's). The legal basis of this program is based on a memorandum of understanding between the stakeholders involved and Islamic sharia.
\end{abstract}

Keywords: Business model canvas, financial inclusion, financing, MAWAR program, and MSME's.

\section{Introduction}

Empowerment of micro and small enterprises in Indonesia including Semarang is still very much needed considering that all kinds of problems faced by micro and small enterprises both internal and external are still quite complex. Moreover, in the era of globalization competition requires micro and small enterprises to continue to innovate in terms of products and services, human resource capacity development, technology renewal, expansion of the marketing area, and strengthening aspects of capital (Gunartin, 2017). There is no doubt regarding the existence of micro and small enterprises especially their contribution to the macroeconomy both in regional and national contexts. According to Fatoki and Asah (2011), the most obvious thing is the contribution of MSME socially and economically through increased employment opportunities and innovation, so that MSME can be a catalyst for regional growth in both rural and urban areas. This was justified by Maryati (2014), the

\section{How to cite:}

Chasanah, A N., Budiantoro, R. A., Putra, F. I. F. S., \& Herawati, R. (2021). Mawar (Melawan Rentenir): Integrated Msme's Financial Inclusion Strategy In Sharia-Based. $3^{\text {rd }}$ Economics, Business, and Government Challenges 2020. NST Proceedings. pages 33-45. doi: 10.11594/ nstp.2021.1306 
important role of micro small, and medium enterprises for the community was felt in the form of economic and limited skills improvement. With the existence of MSME, it is expected to be able to overcome one of the main problems such as unemployment, because, with the increasing number of MSMEs available, the employment rate will be higher, vise versa.

Table 1. MSME Data in Indonesia, Central Java Province and Semarang City, 2015-2019

\begin{tabular}{|c|c|c|c|c|c|}
\hline & 2015 & 2016 & 2017 & 2018 & 2019 \\
\hline $\begin{array}{l}\text { Number of MSMEs in } \\
\text { Indonesia (unit) }\end{array}$ & $59,262,772$ & $61,651,177$ & $62,922,617$ & $64,194,057$ & $66,023,980$ \\
\hline $\begin{array}{l}\text { Number of MSMEs in } \\
\text { Central Java (unit) }\end{array}$ & 108,937 & 115,751 & 133,679 & 143,738 & 156,109 \\
\hline $\begin{array}{l}\text { Number of MSMEs in } \\
\text { Semarang (unit) }\end{array}$ & 17,691 & 19,203 & 20,715 & 22,227 & 23,738 \\
\hline $\begin{array}{l}\text { Number of MSMEs in } \\
\text { Indonesia (people) }\end{array}$ & $110,807,864$ & $112,828,610$ & $116,431,224$ & $116,978,631$ & $113,579,550$ \\
\hline $\begin{array}{l}\text { Number of MSMEs in } \\
\text { Central Java (people) }\end{array}$ & 740,740 & 791,767 & 918,455 & $1,043,320$ & $1,132,178$ \\
\hline $\begin{array}{l}\text { Number of MSMEs in } \\
\text { Semarang (people) }\end{array}$ & 25,627 & 27,601 & 29,576 & 31,551 & 33,526 \\
\hline
\end{tabular}

The practice of micro and small enterprises experiences various difficulties in running their businesses, where capital problems are the main obstacle because most of the capital is sourced from internal capabilities and the informal sector (such as middlemen or acquaintances). According to Rahaman (2011), this capital factor is the most important part of business activities because it relates to overall operations, without easy access to capital will certainly hamper and lead to vulnerability of the sustainability and improvement of business potential. Various methods are used to increase access to the financial institution's industry so that capital problems can be overcome. Accessibility both formally and informally will reduce the problems of MSME, especially in the credit constraints that can be used for initial investment and business development (Beck et al., 2015).

Therefore, the Semarang City Government through the Development Planning Agency at SubNational Level of Semarang, Field of Research and Economic Development prepared and arranged programs specifically relating to financial assistance to the micro and small business sector. In the process of building this linkage program, the main thing was shown through the signing of a memorandum of understanding between the agencies involved, including several Sharia People's Financing Banks, Semarang City Amil Zakat Agency, Semarang Sharia Economic Community, Department of Cooperatives, and Micro Enterprises in Semarang, telecommunication company, branchless banking agents and financial technology institutions, in creating a financing program called the Mawar Program (Against Moneylenders) based on the Murabahah contract to MSME in Semarang.

In essence, murabahah is selling products at a production selling price known by seller and customer with clear profit, so murabahah means mutual benefit. Murababah is goods purchasing with a deferred payment within 1 month, 2 months, 3 months, and an agreed period. Murabahah financing is provided to customers to fulfill production needs (inventory)

The next step is the development of the Mawar Program (Against Moneylenders) in collaboration with financial technology institutions to strengthen the screening process of prospective beneficiary customers and telecommunications companies that conduct payment activities through their mobile banking. The thing that emphasizes the Mawar Program (Against

Moneylenders) is to provide financial assistance and empowerment for micro and small enterprises in Semarang so that in the future it can be economically independent, and provide 
a multiplier effect for the surrounding environment. Furthermore, it is expected that more Mawar (Against Moneylenders) acceptance will be able to receive benefits from this program and be on target. This is in line with Development Planning Agency at the Sub-National Level of Semarang City (2019) in Regional Medium Term Development Plan of Semarang City for 2005-2025, MSMEs are required to be able to develop a society-based economy so that they have high competitiveness with large capital owners.

Starting from the background of the existing problems, to encourage the growth of integrated financial inclusion that can be the basis for strengthening the creative economy sector and leading regions, especially in the city of Semarang as a foundation for sustainable economic growth improvement, increased economic welfare and income distribution efforts. So this research seeks to develop a model and formulation of an integrated financial inclusion strategy in sharia-based micro and small business financing in the more productive Semarang City. In accordance with the problems above, this research has the following objectives:

- Obtaining problems from workers in the micro and small business sector in the city of Semarang Getting modeling concepts from the Mawar Program (Against Moneylenders)

- Acquire the role that must be carried out by the stakeholders involved in Mawar Program (Against Moneylenders)

\section{Research urgency}

Besides, it is expected the zakat practitioners, especially in the Semarang City to optimize the collection and distribution of zakat, infaq, and alms funds in empowering MSMEs. The expected benefits of this research can be used for important consideration and input for the Semarang City Government, particularly the Regional Development Planning Agency of Semarang,

Research Field and Economic Development to perform various implementation steps in making policy and regulation to become the foundation of sustainable community development through strengthening integrated financial inclusion to create micro and small enterprises that are competitive, independent, prosperous, and cultured based on religious values. In addition, it is expected that zakat practitioners, especially those in Semarang, will optimize the collection and distribution of zakat, infaq, and alms funds in empowering micro and small enterprises.

\section{Literature review \\ Concept of empowerment}

The concept of empowerment based on etymology is derived from the word "power" which means strength and ability. In this case, it means trying to facilitate the socio-economically weak community groups in various ways such as providing education related to the development of their potential and training programs so that they can be free from previous conditions of powerlessness. The success of the empowerment program can be reviewed from the fulfillment of the principles that must be met.

The context of empowerment to micro and small enterprises must be following their ideal needs, both in technical and institutional terms so that they can contribute to the economy optimally. According to Perkins and Zimmerman (1995), the definition of empowerment is to give power to people with weak categories, or in this case disadvantaged. The context of empowerment becomes a strategic tool for renewing and improving performance, raising awareness, encouraging, motivating the potential of organizations, government, and business activities including in the micro and small enterprises. 
Table 2. Principle of empowerment

\begin{tabular}{ll}
\hline Principle & Definition \\
\hline Equality & $\begin{array}{l}\text { Efforts to position the equality relationship based on the knowledge, expertise, } \\
\text { and experience a person has with the institutions that carry out community em- } \\
\text { powerment programs. } \\
\text { Participation }\end{array}$ \\
$\begin{array}{l}\text { Efforts to stimulate the independence of the community because the basis of em- } \\
\text { powerment is participatory planned, implemented, monitored, and evaluated so } \\
\text { that the goal will be optimal. } \\
\text { Independence }\end{array}$ & $\begin{array}{l}\text { Efforts to respect and prioritize the potential of a person related to independence } \\
\text { so that they do not depend on other parties. } \\
\text { Sustainability } \\
\text { Efforts to plan empowerment programs sustainably, until, in the end, someone can } \\
\text { be independent and more empowered. }\end{array}$
\end{tabular}

Source: Najiyati et al. (2005)

The important thing in determining the ideal empowerment concept to improve the competitiveness of micro and small enterprises starts from defining what and how the criteria of micro, small and medium enterprises apply in general. However, the problem is the absence of standardized and universally applicable definitions associated with micro, small and medium enterprises in Indonesia. Because the classification of this sector with consideration of the value of net assets owned and the value of the sales obtained by micro, small and medium enterprises following those listed in Law No. 20 of 2008, concerning Micro, Small and Medium Enterprises, with the following details:

Table 3. Definition and criteria for micro, small and medium enterprises

\begin{tabular}{|c|c|}
\hline $\begin{array}{l}\text { Scale } \\
\text { Enterprises }\end{array}$ & Definition and Criteria \\
\hline Micro & $\begin{array}{l}\text { Productive enterprises owned individually or an individual company that meets the } \\
\text { applicable micro-enterprises criteria (generally a type of home industry consisting } \\
\text { of 1-4 people) }\end{array}$ \\
\hline Enterprises & $\begin{array}{l}\text { The maximum net worth owned by this sector is IDR } 50 \text { million (this amount does } \\
\text { not include land and buildings from the place of business) }\end{array}$ \\
\hline & Getting the most sales results in a year of IDR 300 million \\
\hline \multirow{3}{*}{$\begin{array}{l}\text { Small } \\
\text { Enterprises }\end{array}$} & $\begin{array}{l}\text { Productive enterprises with operations carried out independently by individuals or } \\
\text { an individual company that are not included in subsidiaries or branches directly or } \\
\text { indirectly of medium or large enterprises (in small businesses the number of } \\
\text { workers employed is more or less } 5 \text { to } 19 \text { people) }\end{array}$ \\
\hline & $\begin{array}{l}\text { Total net worth owned by this sector ranges from IDR } 50 \text { million to a maximum of } \\
\text { IDR } 500 \text { million (this amount does not include land and buildings from the place of } \\
\text { business) }\end{array}$ \\
\hline & $\begin{array}{l}\text { Getting sales results in a year ranges from IDR } 300 \text { million to a maximum of IDR 2,5 } \\
\text { billion }\end{array}$ \\
\hline
\end{tabular}

To be continued.... 
Productive enterprises with operations carried out independently by individuals or an individual company that are not included in subsidiaries or branches directly or indirectly of small and large enterprises (in medium enterprises the number of

Medium Enterprises workers employed is approximately 20 to 99 people)

Total net worth owned by this sector ranges from IDR 500 million to a maximum of IDR 10 billion (this amount does not include land and buildings from the place of business)

Getting sales results in a year ranges from IDR 2,5 billion to IDR 10 billion

Source: Law No. 20 of 2008 concerning Micro, Small and Medium Enterprises

\section{Development strategy and concept of empowerment in Islam}

One practice of empowerment in Islam can be done by utilizing the zakat, infaq, and alms (ziswaf), which muzakki can empower mustahiq (people in need). According to Wahid (2010), the concept of empowerment in Islam as an effort to develop the potential of the principles as follows:

- $\quad$ Reducing the burden

Every individual is a weak creature, meaning that there is a limit in the ability they have. Islamic teachings guide doing a job to complete before doing other work, so the results will be optimal. This is following Q.S Asy-Syarh verse 7:

فَاِذاذَا فَرَغْتَنَ فَانْصَبْ

Meaning: "So when you have finished (from one matter), work earnestly the other (matter)"

- $\quad$ Eliminate poverty

The impact of minimizing the burden on individuals is expected to reduce or eliminate poverty. Poverty is defined as being outside the limits of individual abilities, not tired, lazy, and hard to develop one's potential. But that does not mean that one can avoid the existence of poverty because in Islam this poverty or distress is part of God's test of obedience and devotion to Him. This is following QS. Al Mulk verse 2:

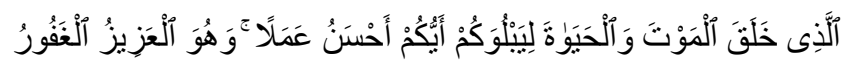

Meaning: "Who made death and life, so that He tests you, which of you is better in charity. And He is Mighty, Most Forgiving"

\section{Financial inclusion}

According to the Asian Development Bank through the 2020 strategy, defining financial inclusions is the focus of the two strategies which are sustainable income growth and opportunities open to all parties to access formal financial institutions. This was confirmed by Hanig and Jansen (2010) for encouraging inclusive growth, it is necessary to encourage three comprehensive policy pillars, which are: (1) good governance, (2) strong institutions, and (3) protection for the community. Looking at its history, financial inclusion has been widely practiced and is the focus of various governments and central banks in various countries including in Indonesia since 2000. According to Sreeramulu (2013), proving that financial inclusion in India contributes greatly to the poor through easy access to the system's lowcost financial and credit services that will increase its potential. India's financial literacy rate has increased over a decade from 35.5 percent (2001) to 58.7 percent (2011). Whereas in Peru, there was an expansion of financial access for the community, especially in the portfolio of products from financial services (loans, deposits, insurance, pensions, payment systems, financial education, and consumer protection (Reyes, 2010). In Indonesia, financial inclusion is also at the forefront, as a national 
strategy to encourage economic growth by distributing equitable income distribution, poverty reduction, and financial system stability (Hadad, 2010). The same thing was expressed by Bank Indonesia (2014), the target of financial inclusion policies in Indonesia is to pay attention to the poor who have low incomes, the poor but productive, and people who live far from access to financial institutions.

\section{Research Method}

\section{Research approach}

This research proposal used a qualitative approach with Business Model Canvas analysis, based on the consideration that this method can explain, assess, and visualize and change modeling including financing and empowerment models in sharia-based leading micro and small enterprises sectors through the Mawar Program (Against Moneylenders) rationally, comprehensive and more optimal.

\section{Data types and sources}

The type of data used was a combination of primary data from results and secondary data that supports studies in formulating financing and empowerment modeling in the sharia-based leading micro and small enterprises sector through the Mawar Program (Against Moneylenders). Data sources in this case study research were obtained through observation (field research), interviews, and other literature studies.

Direct observation technique, the researcher directly observed the state of the object which was the practice of micro and small enterprises in Semarang

Interview technique, which was done with depth interview both from the manager of the Mawar Program (Against Moneylenders) as well as micro and small enterprises as a target when researcher conducted direct observations

Observation and literature techniques, which were obtained from several reports issued by agencies involved in the implementation of the Mawar Program (Against Moneylenders) and some literature.

In the research flow scheme, starting from the potential of micro and small enterprises in Semarang, where the majority comes from home industries. The Semarang City Government collaborates through a memorandum of understanding with other agencies to provide strategic solutions in sharia-based financing models for potential micro and small enterprises.

There is integration with stakeholders through this program, which is based on sharia to determine policy direction, provide access to potential micro and small enterprises in financing. This program is used by the Semarang City Government to increase the capacity and eligibility of MSMEs to access financial institutions and encourage financial institutions to be able to provide financing services to MSMEs. 


\section{Flow and conceptual framework research}

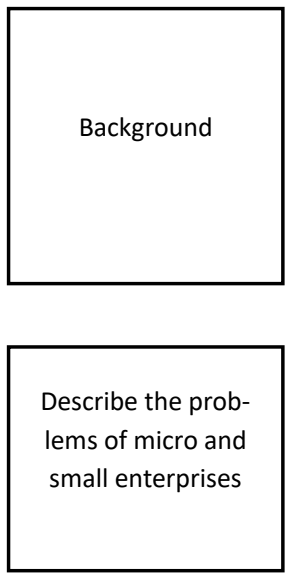

\begin{tabular}{c}
$\begin{array}{c}\text { Formulate research } \\
\text { questions }\end{array}$ \\
\hline
\end{tabular}

Data Collection

(primary and secondary)

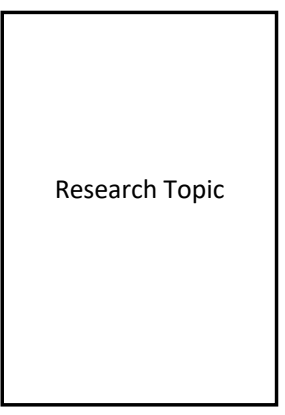

Output

Outcome

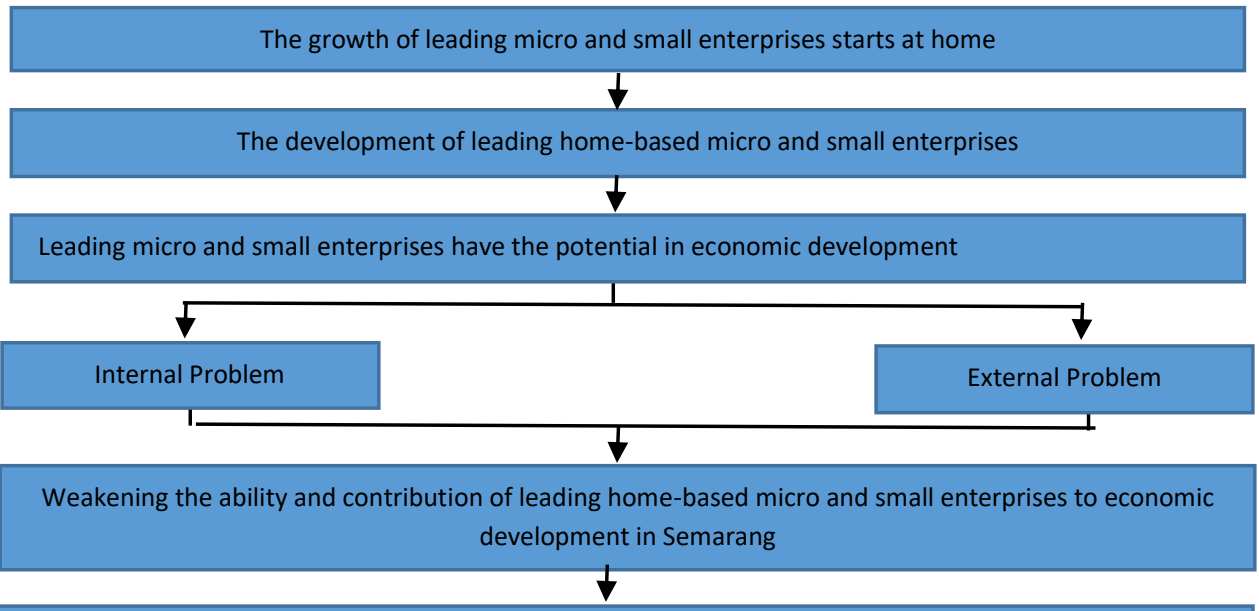

- What problems are faced by micro and small businesses in Semarang?

- How does the concept of modeling Mawar Program (against moneylenders)?

- What is the role of each stakeholder involved?

\section{Obtained from:}

- Interview (stakeholders and micro and small enterprises)

- Direct observation

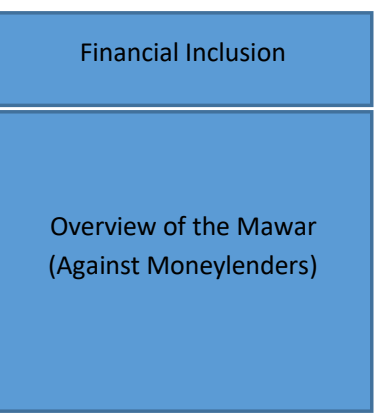

Pergeseran Pembiayaan dari Sektor Informal menuju Formal

- Terms dan Criterias

- Program Scheme and Legal Basis

- Roadmap of Mawar Program

- Role of the Stakeholders Involved

- Compliance with the Semarang Regional Long and Mid Term

Development Plan

- Business Model Canvas

Strategic financing and empowerment models through the Sharia-based Mawar (Against Moneylenders) linkage program in Semarang

\section{1}

Micro and small enterprises in Semarang that are competitive, independent, prosperous, and cultured on the values of religiosity

Figure 1. Research flow 


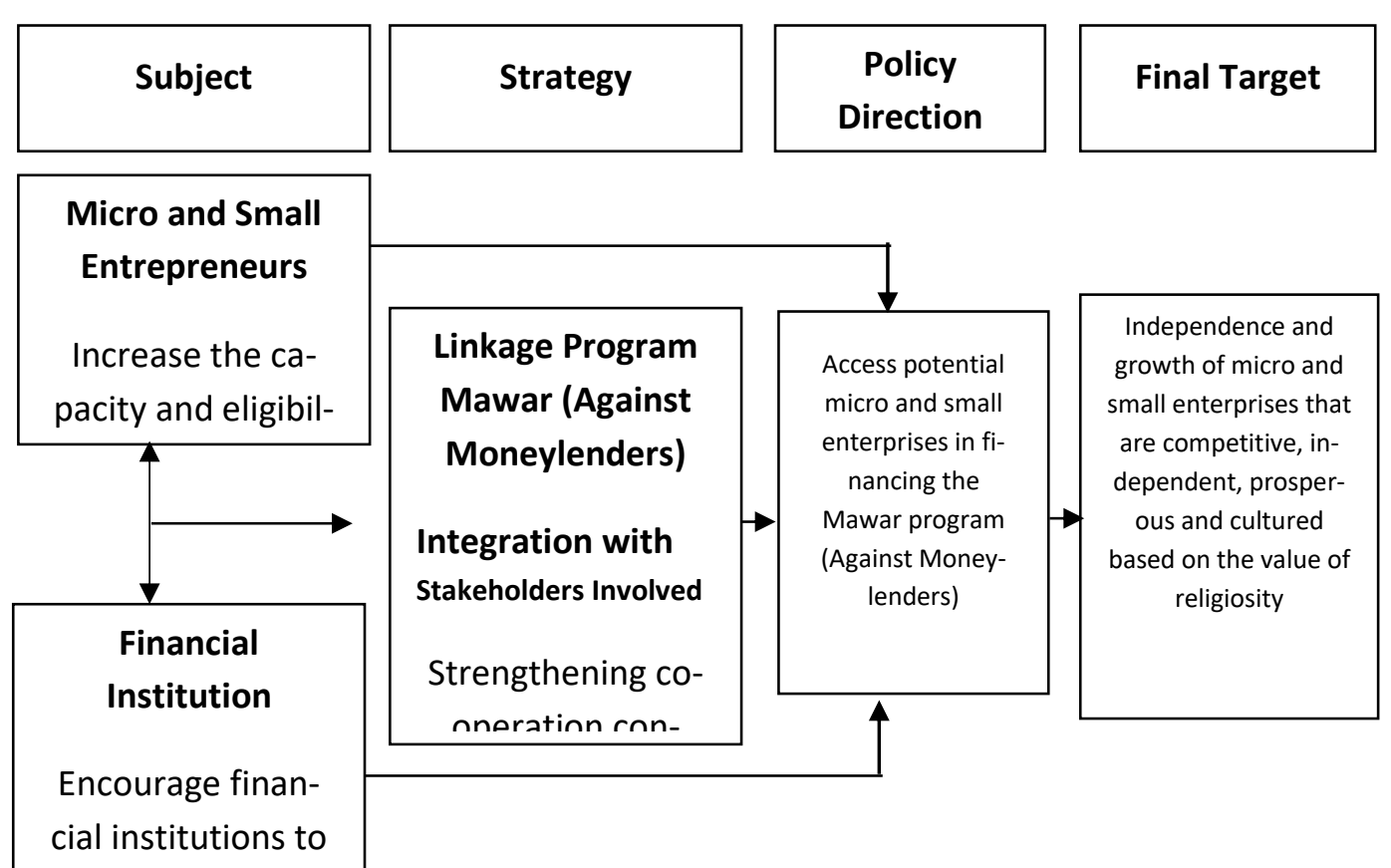

Figure 2. Inclusive Financial Policies in Financing the Micro and Small Enterprises Sector (Permata, 2017; modified)

\section{Analysis tools}

The analytical tool used was the business canvas model which was considered appropriate in designing business models, including compiling a sharia-based financing model initiated by the Semarang City Government for potential micro and small enterprises (Tjitradi, 2015). This was justified by Osterwalder et al. (2010), where the business canvas model will show a logical picture of a business model and how an agency creates, delivers, and captures a value. The way of thinking from this canvas is by dividing the business model into nine main components, where the components are on the right side (showing creativity) and on the left side (showing logic) as follows (see Figure 3 and Table 4): (1) customer segment; (2) customer relationship; (3) customer channel; (4) revenue structure; (5) value proposition; (6) key activities; (7) key resource; (8) cost structure, dan (9) key partners.

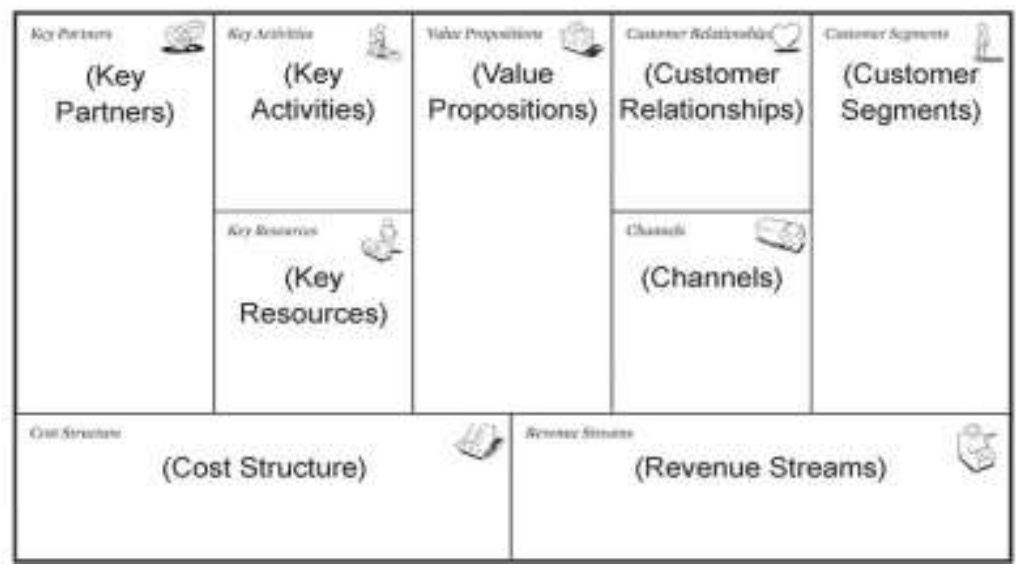

Figure 3. Nine Major Components in Business Model Canvas (Source: Tjitradi, 2015) 


\section{Results and Discussion}

The main Mawar Program (Against Moneylenders) is more directed to provide effective solutions to internal aspects problems, especially in the limited financial resources, both initial capital investment and business expansion carried out by the micro and small business sector. This is in line with Bank Indonesia's research (2011) which showed that the sources of funds owned by MSMEs tend to be limited because they only come from the internal sector (own capital), if there are other sources, capital in the micro-business sector is supported by the informal sector (such as middlemen or acquaintance) so that it will directly or indirectly hamper the development of its business operations the main obstacle of the limited capital of micro and small enterprises is the difficulty in accessing finance to the formal sector because these micro and small entrepreneurs still do not understand and understand how to obtain it. On the other hand, financial institutions that have liquidity and can provide funds to micro and small entrepreneurs also experience difficulties in achieving these financing targets.

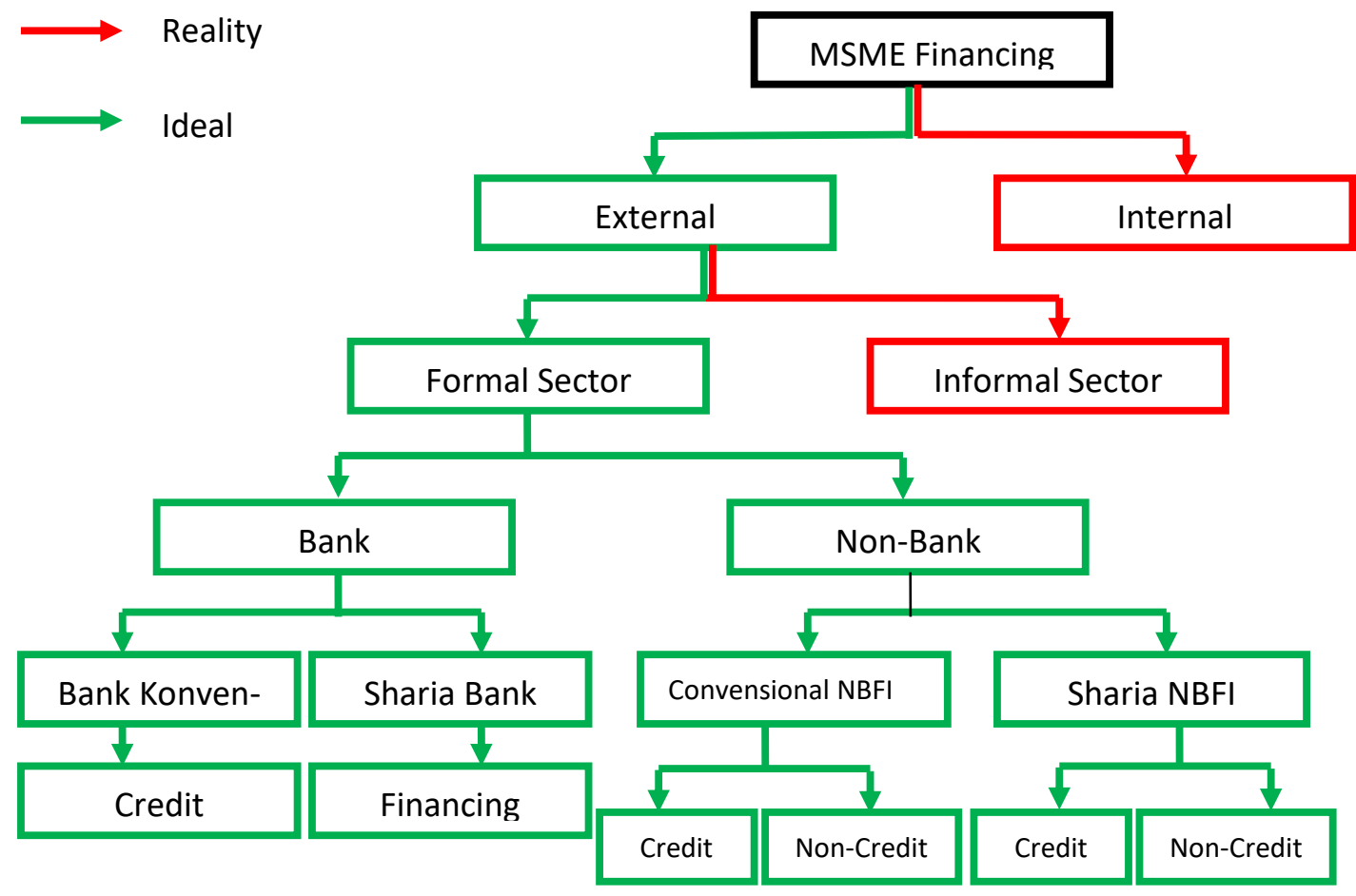

Figure 4. The flow of micro and small enterprises financing (Source: Dewi, 2018; modified)

Ideally, the financing mechanism for micro and small entrepreneurs is carried out by formal financial institutions, both banks, and non-bank financial institutions. But in reality, micro and small entrepreneurs only get capital from the internal sector or the informal sector. This is due to the massive number of micro and small entrepreneurs in Indonesia, especially those in Semarang, and the large contribution to the macroeconomy, especially in providing employment and its contribution to GDP and GRDP.

The Mawar Program (Against Moneylenders) comes as an effort made by the Semarang City Government as a form of encouragement of financial inclusion programs in the micro and small enterprises sector so that it will move funding sources which originate from the informal and internal sectors to the formal sector. Therefore, this deficiency will be the basis for the formulation of a policy 
strategy for financing assistance to potential micro and small entrepreneurs based on sharia through the Mawar Program in Semarang.

\section{Overview of mawar program (Against Moneylenders)}

The Semarang City Government, through the Semarang City Regional Development Planning Agency, Research and Economic Development, initiated a funding assistance program for potential micro and small entrepreneurs based on sharia (Murabahah contract) by collaborating through a memorandum of understanding with several other agencies, such as: several Sharia People Financing banks, Semarang City Amil Zakat Agency, Semarang Syariah Economic Community, Semarang City Cooperatives and Micro Enterprises Agency, telecommunications companies, branchless banking agents and financial technology institutions. One of the benefits gained from the Mawar Program (Against Moneylenders) is that the Semarang City Government does not charge any additional costs to micro and small entrepreneurs. The legal basis of this program is based on a memorandum of understanding between the stakeholders involved. In general, an overview of the Mawar Program (Against Moneylenders) can be seen in the following Figure 5:

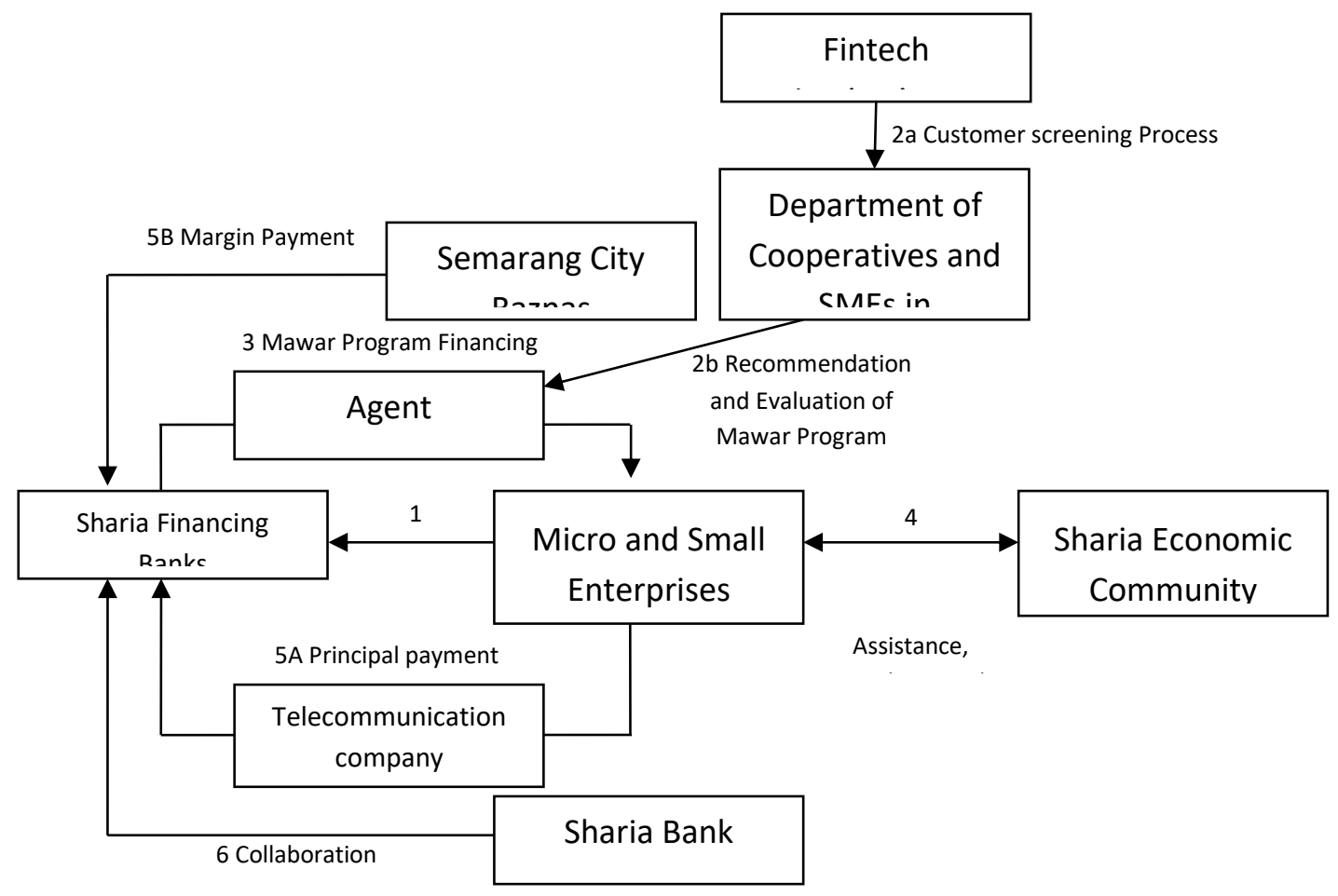

Figure 5. Financing Scheme of Sharia Business Mawar Program (Source: Bank Indonesia and Airlangga University, 2016; modified)

The Mawar Program (Against Moneylenders) is planned and developed with the hope of increasingly optimal financing provided to micro and small entrepreneurs in the city of Semarang, both in terms of quality and quantity. For micro and small entrepreneurs who receive financial assistance, it is expected to be able to upgrade the class, from previously micro businesses to small or medium or even large scale, so that the multiplier effect in the economy can be realized. Micro and small entrepreneurs participating in this financing program must complete several required administrative requirements, including: 
Table 4. Criterias and requirements for the administration of micro and small entrepreneurs to join the mawar program (against moneylenders)

\begin{tabular}{|c|c|c|c|}
\hline No. & Criterias & No. & Requirements \\
\hline 1 & $\begin{array}{l}\text { The customer is a citizen of Semarang City } \\
\text { (proven by Semarang City ID card) }\end{array}$ & 1 & Photocopy of the applicant's ID card \\
\hline 2 & $\begin{array}{l}\text { Operating assets less than IDR } 500 \text { million } \\
\text { (included in the size of micro and small } \\
\text { enterprises) }\end{array}$ & 2 & $\begin{array}{l}\text { Photocopy of the applicant's family } \\
\text { card }\end{array}$ \\
\hline 3 & $\begin{array}{l}\text { Written recommendation from Department of } \\
\text { Cooperative and Micro Enterprises of } \\
\text { Semarang and Baznas of Semarang (processed } \\
\text { by Baznas of Semarang) }\end{array}$ & 3 & $\begin{array}{l}\text { Application letter to the Sharia } \\
\text { Financing Bank }\end{array}$ \\
\hline 4 & $\begin{array}{l}\text { Do not have loan arrears to the Semarang City } \\
\text { Cooperative and Micro Business Agency } \\
\text { (blacklist) or other financial institutions }\end{array}$ & 4 & $\begin{array}{l}\text { Photocopy of Business Licence / } \\
\text { Letter of Statement from Headman }\end{array}$ \\
\hline \multirow[t]{3}{*}{5} & $\begin{array}{l}\text { Willing to open a savings account at one of the } \\
\text { designated Sharia Financing Banks in the city } \\
\text { of Semarang for business activities }\end{array}$ & 5 & $\begin{array}{l}\text { Photocopy of STDP / Letter of } \\
\text { Statement from Headman }\end{array}$ \\
\hline & & 6 & Original guarantee \\
\hline & & 7 & Site plan \\
\hline
\end{tabular}

Source: Department of Cooperative and Micro Enterprises (2019), modified

Given the massive contribution of micro and small entrepreneurs to the macroeconomy both regionally and nationally. The Mawar Program (Against Moneylenders) is considered appropriate in carrying out a linkage program for sharia-based financing and encouraging financial inclusion as an effort to answer problems for micro and small entrepreneurs in Semarang. So in the future, a variety of in-depth studies and analyzes are needed, one of them is by using a business canvas model to maximize the Mawar Program (Against Moneylenders) in managing to finance to potential micro and small entrepreneurs. 
Table 5. Business canvas model in mawar program (Against moneylenders)

\begin{tabular}{|c|c|c|c|c|c|}
\hline \multirow{2}{*}{$\begin{array}{l}\text { KEY PARTNERSHIP } \\
\text { Semarang City } \\
\text { Government } \\
\text { (Department of } \\
\text { Cooperative and Micro } \\
\text { Enterprises) } \\
\text { Sharia Financing Banks } \\
\text { Sharia Economic } \\
\text { Community } \\
\text { Semarang } \\
\text { Baznas of Semarang } \\
\text { Telecommunication } \\
\text { company } \\
\text { Branchless banking } \\
\text { agents } \\
\text { Sharia Banks } \\
\text { Financial technology } \\
\text { company }\end{array}$} & $\begin{array}{l}\text { KEY ACTIVITIES } \\
\text { Development or } \\
\text { maintenance of a } \\
\text { financing platform } \\
\text { Strengthen the role of } \\
\text { stakeholders involved in } \\
\text { managing the Mawar } \\
\text { Program } \\
\text { Build or maintain micro } \\
\text { and small enterprises } \\
\text { with sharia financial } \\
\text { institutions }\end{array}$ & \multirow{2}{*}{\multicolumn{2}{|c|}{$\begin{array}{l}\text { VALUE PROPOSITION } \\
\text { Increased financial inclusion } \\
\text { or access to formal financial } \\
\text { institutions for micro and } \\
\text { small entrepreneurs } \\
\text { Capacity building of micro and } \\
\text { small entrepreneurs } \\
\text { Increasing the use of zakat, } \\
\text { infaq and alms funds in } \\
\text { Semarang }\end{array}$}} & $\begin{array}{l}\text { CUSTOMER } \\
\text { RELATIONSHIP } \\
\text { Human } \\
\text { IT (platform) } \\
\text { The socialization of } \\
\text { the benefits of } \\
\text { sharia-based } \\
\text { financing to micro } \\
\text { and small } \\
\text { entrepreneurs }\end{array}$ & \multirow{2}{*}{$\begin{array}{l}\text { CUSTOMER SEGMENTS } \\
\text { Micro and small entrepreneurs } \\
\text { Citizens of Semarang } \\
\text { Following the criteria of micro and small } \\
\text { entrepreneurs } \\
\text { A business sector that is halal and following } \\
\text { Islamic Law } \\
\text { Does not conflict with the concept of } \\
\text { sustainable development } \\
\text { Meet the criteria and administrative } \\
\text { requirements Fostered by the Department of } \\
\text { Fooperative and MSME of Semarang } \\
\text { Coof }\end{array}$} \\
\hline & $\begin{array}{l}\text { KEY RESOURCES } \\
\text { IT and internet } \\
\text { infrastructure } \\
\text { HR managerial skills } \\
\text { (internet utilization, fund } \\
\text { management, and } \\
\text { business development) }\end{array}$ & & & $\begin{array}{l}\text { CHANNELS } \\
\text { Stakeholders of } \\
\text { Mawar Program } \\
\text { Sharia Financial } \\
\text { Institutions (Sharia } \\
\text { Financing Banks) } \\
\text { Community of micro } \\
\text { and small } \\
\text { entrepreneurs }\end{array}$ & \\
\hline \multicolumn{3}{|c|}{$\begin{array}{l}\text { REVENUE STREAMS } \\
\text { Profit-sharing from fund management with murabahah contracts }\end{array}$} & \multicolumn{3}{|c|}{$\begin{array}{l}\text { COST STRUCTURE } \\
\text { Costs for developing and maintaining platforms and infrastructure } \\
\text { HR costs } \\
\text { Operational costs }\end{array}$} \\
\hline
\end{tabular}




\section{Conclusion}

The Mawar Program (Against Moneylenders) seeks to address the problems that occur. The program was initiated by the Semarang City Government, especially the Semarang City Regional Development Planning Agency, Research, and Economic Development Division, which collaborated through a memorandum of understanding with several other stakeholders including the Semarang City Baznas, the Sharia Financing Bank in Semarang, the Sharia Economic Community in Semarang, the Department of Cooperatives and SMEs in Semarang, telecommunications companies, financial technology companies, Islamic banking, and branchless banking agents. This program is a concrete form of support in empowering micro and small entrepreneurs through the provision of financial assistance with sharia principles and other technical and managerial assistance. It is expected that micro and small entrepreneurs who receive these benefits can develop to become more prosperous, independent, and cultured based on religious values.

The success of the Mawar Program (Against Moneylenders) is determined by the seriousness of each stakeholder in carrying out their roles and responsibilities as well as possible. Sharia Financing Bank plays a role in providing funds to be given to micro and small entrepreneurs in Semarang. Semarang City Baznas plays a role in bearing other costs arising from the Mawar Program (Against Moneylenders) so that these costs are not borne by micro and small entrepreneurs. The Department of Cooperatives and SMEs in Semarang issues a letter of recommendation for financing feasibility to potential micro and small entrepreneurs. While the Semarang City Sharia Economic Community plays a role to keep the Mawar Program in Sharia corridor and provides assistance, guidance, and training to micro and small entrepreneurs. Then the financial technology company provides a feasibility assessment of the distribution of funding to micro and small entrepreneurs through machine learning and big data and advanced analytics.

\section{References}

Beck, T., Demirguc-Kunt, A., \& Peria, M. S. M. (2008). Bank financing for SMEs around the world: drivers, obstacles, business models, and lending practices. The World Bank, Policy Research Working Paper Series, 4785, 1-43

Bank Indonesia. (2014). Global financial development report 2014: Financial inclusion. Jakarta: Departemen Pengembangan Akses Keuangan dan UMKM Bank Indonesia.

Departemen Ekonomi dan Keuangan Syariah, Bank Indonesia and Departemen Ekonomi Syariah Fakultas Ekonomi dan Bisnis, Universitas Airlangga. (2016). Wakaf: Pengaturan dan Tata Kelola yang Efektif. Seri Ekonomi dan Keuangan Syariah.

Dewi, E. M. (2018). Inbank: Strategi integrasi lembaga keuangan untuk penyaluran kredit mikro di Indonesia: 1-20. http://Pilmapres.Ristekdikti. Go.Id/File/Kti/Sarjana_Ips_Evita_Martha_Dewl 18016662 KTI.pdf

Fatoki, O., \& Asah, F. (2011). The impact of firm and entrepreneurial characteristics on access to debt finance by SMEs in King Williams' Town, South Africa. International Journal of Business and Management, 6(8), 170-9. Doi:10.5539/ijbm.v6n8p170

Gunartin, (2017). Penguatan UMKM sebagai pilar membangun ekonomi bangsa. Eduka: Jurnal Pendidikan, Hukum, dan Bisnis, 2(2), $46-55$.

Hadad, M. D. (2010). Developing a financial inclusion strategy: The case of Indonesia yang disampaikan pada The 2010 AFI Global Policy Forum, 27-29 September 2010 di Bali https://www.afi-global.org/sites/default/files/bi-muliamanhadaddevelopingafinancialinclusionstrategy-thecaseofindonesia.pdf

Hannig, A., \& Jansen, S. (2010). Financial inclusion and financial stability: current policy issues. ADBI working paper 259. Tokyo: Asian Development Bank Institute.

Maryati, S. (2014). Peran Bank Pembiayaan Rakyat Syariah dalam Pengembangan UMKM dan Agribisnis Pedesaan di Sumatera Barat. Journal of Economic and Economic Education, 3(1), 1-17. Doi: 10.22202/economica.2014.v3.i1.231

Najiyati, S., Asmana, A., \& Suryadiputra, I. N. N. (2005). Pemberdayaan Masyarakat di Lahan Gambut. Bogor: Wetlands International.

Osterwalder, Alexander, \& Pigneur, Y. (2010). Business model generation: A handbook for visionaries, game changers, and challengers. New Jersey: ohn Wiley \& Sons, Inc.

Permata, M. I. (2015). Peran Bank Indonesia dalam pengembangan UMKM. Seminar Daerah, 4 Juni 2015 di Universitas Jambi,. https://slideplayer.info/slide/5304122/

Perkins, D. D., \& Zimmerman, M. A. (1995). Empowerment theory, research, and application. American Journal of Community Psychology, 23(5), 569-79

Rahaman, M. M. (2010). Access to Financing and Firm Growth. Journal of Banking and Finance, 35, 1-48

Reyes, G. P. (2010). Financial inclusion indicators for developing countries: The peruvian case. Peru: Superintendency of Banking.

Sreeramulu, S. M., (2013). A financial inclusion in India - An Assessment. Mumbai: Reserve Bank of India https://rbidocs.rbi.org.in/rdocs/Speeches/PDFs/MFl101213FS.pdf

Tjitradi, E.C. (2015). Evaluasi dan perancangan model bisnis berdasarkan business model canvas. Jurnal Agora, 3(1), 8-16.

Wahid, A. (2015). Prinsip-prinsip pemberdayaan menurut Al-Qur'an: Kajian tematik tentang ayat-ayat pemberdayaan masyarakat. Syaikhuna, $6(2), 208-22$. 